\title{
Booknotes/ Notes de Lectures
}

Édifier ou instruire? Les avatars de la liturgie réformée du XVI au XVIII siècle. Éd. Maria-Cristina Pitassi. Collection «Vie des Huguenots ». Paris, H. Champion, 2000. P. 143.

Actes d'une journée d'études commune à l'École Pratique des Hautes Études de Paris (section des Sciences religieuses) et à l'Institut de la Réformation de Genève, les six textes rassemblés ici avec une préface d'Olivier Fatio étudient la liturgie réformée dans ses sources, son évolution et ses crises sur la période signalée par le titre. Bernard Roussel, «Des rituels luthériens à la liturgie réformée », pose des questions de méthode et d'historiographie à propos de la notion de rituel. On trouve dans cette contribution l'équivalent d'un état actuel XVII siècle dont celles de Christian Grosse, de Marianne Carbonnier-Burkard et de Francis Higman. Le premier, auteur d'une remarquable thèse sur la cène réformée, étudie l'émergence d'une orthodoxie rituelle au début du XVII ${ }^{\mathrm{e}}$ siècle. Il s'agit des enjeux d'une crise portant sur les modalités de la célébration eucharistique (hostie ou pain commun ? distribution par le seul pasteur? paroles d'exhortation au moment de la distribution ?). Il apparait que Genève se plie à un modèle réformé uniforme, cléricalisé au nom de la « dignité » du sacrement. On s'éloigne des modèles qui s'étaient affirmés à l'époque de la Réforme. La seconde, avec «Le temps de la cène chez les réformés français », s'intéresse à la périodicité (quatre temps), aux circonstances et aux pratiques de célébration, ainsi qu'à l'apparition d'une littérature de préparation à la communion, qui souligne le moment individuel en le mettant de plus en plus an avant. Le troisième article, «La fortune de la Forme des prières en Grande-Bretagne jusqu'au milieu du XVII ${ }^{e}$ siècle », montre comment la liturgie anglo-genevoise, fruit d'un travail collectif de Knox, Whittingham, Gilby, Fox et Cole, et qui a eu un succès considérable outre-Manche, est un compromis déséquilibré entre celle de Calvin et le Book of Common Prayer. Il y est question aussi du baptême, du mariage et de la visitation des malades. Les deux contributions qui suivent concernent le $\mathrm{XVIII}^{\mathrm{e}}$ siècle. Dans l'ensemble, les textes ici rassemblés éclairent de manière 
nouvelle les questions abordées, et soulèvent des questions historiques, littéraires et anthropologiques intéressantes.

\section{OLIVIER MILLET, Université de Bâle}

R. A. Foakes. Shakespeare and Violence. Cambridge: Cambridge University Press, 2003. Pp. xiii, 224.

R. A. Foakes aims in Shakespeare and Violence to chart the development of Shakespeare's thinking about violence over the course of his dramatic career. Foakes argues that Shakespeare's plays "may be seen as following a trajectory that begins with a delight in representing violence for entertainment, continues in a series of plays that explore various aspects of the problem of violence, and ends with a searching study of human aggression in relation to self-control in The Tempest" (p. 2). Adopting René Girard's model of violence as a means of creating status differences between rivalrous but otherwise identical males, the book's fundamental assumption is that human beings (or at least human males) are naturally violent and express their aggressiveness in remarkably similar ways in spite of other cultural differences. Culture in this model is a progressively ameliorating but rather fragile force. The book's Girardian approach produces interesting but at times strained readings of male violence in a range of Shakespeare's plays. Foakes reads the plays in the context of Christian and classical myths of violence, such as the Cain and Abel story and Homeric myth, often in conjunction with analyses of the plays' film adaptations intended to demonstrate that "although Shakespeare's world was very different from that of the present day ... the basic issues remain the same" (ibid.). Foakes's readings are wide-ranging and thought-provoking, but the reader may find their tendency to elide cultural difference problematic and may regret Foakes's decision - explicitly stated at the book's outset — not to address the role of violence in the production of gender distinctions.

\section{MATHEW MARTIN, Brock University}

An Interregnum of the Sign: The Emblematic Age in France, Essays in Honour of Daniel S. Russell. Éd. David Graham. Glasgow Emblem Studies, 6. Glasgow, Department of French, University of Glasgow, 2001. P. 251.

Le présent recueil rassemble onze études offertes à Daniel Russell, professeur à Pittsburgh, en l'honneur de son départ à la retraite. Toutes ces études, proposées par les meilleurs spécialistes de l'emblématique, abordent les rapports du texte et de l'image dans des ouvrages français et néo-latins pendant la Renaissance et au début du XVII ${ }^{\mathrm{e}}$ siècle. Deux articles concernent l'œuvre de Scève (G. Mathieu-Castellani, M. Giordano) ; deux autres celle de Georgette de Montenay (A. Adams, P. Choné); d'autres encore celles de Coustau (A. Saunders), d'Alciat (S. Rawles) et de Woeiriot (P. Choné encore). L'intérêt de ces articles est d'être unis par des préoccupations théoriques, méthodologiques et idéologiques. Ils s'intéressent au premier chef à 